\title{
Hypomagnesemia with Secondary Hypocalcemia Linked to a Novel TRPM6 Gene Mutation
}

\author{
Amel Tej1 ${ }^{*}$, Bernd Dworniczak², Asma Marzouk¹, Najla Soyah ${ }^{1}$, Samia Tilouche¹, Moez Gribaa ${ }^{3}$, \\ Jihène Bouguila ${ }^{1}$, Lamia Boughamoura ${ }^{1,4}$ \\ ${ }^{1}$ Pediatric Department, Farhat Hached, Sousse, Tunisia \\ ${ }^{2}$ Department of Human Genetics, Westfaelishe Wilhelms Universität, Münster, Germany \\ ${ }^{3}$ Department of Human Genetics Farhat Hached, Sousse, Tunisia \\ ${ }^{4}$ Medical faculty Ibn Jazzar, University of Sousse, Sousse, Tunisia \\ Email:`ameltej@yahoo.fr, Bernd.Dworniczak@ukmuenster.de, marzoukasmajaziri@gmail.com,soyahnajla@yahoo.fr, \\ samiatilouche@yahoo.fr,moez_gribaa@yahoo.fr, jbouguila@yahoo.fr, lamia_boughamoura@yahoo.fr
}

How to cite this paper: Tej, A., Dworniczak, B., Marzouk, A., Soyah, N., Tilouche, S., Gribaa, M., Bouguila, J. and Boughamoura, L. (2016) Hypomagnesemia with Secondary Hypocalcemia Linked to a Novel TRPM6 Gene Mutation. Open Journal of Pediatrics, 6, 290-294.

http://dx.doi.org/10.4236/ojped.2016.64040

Received: August 24, 2016

Accepted: November 18, 2016

Published: November 21, 2016

Copyright $\odot 2016$ by authors and Scientific Research Publishing Inc. This work is licensed under the Creative Commons Attribution International License (CC BY 4.0).

http://creativecommons.org/licenses/by/4.0/

\section{(c) (i) Open Access}

\begin{abstract}
Hypomagnesemia with secondary hypocalcemia (HSH) is a rare inherited disorder, characterized by extremely low levels of serum magesium associated with symptomatic hypocalcemia. HSH manifests in the new born period with neurological symptoms, including generalized seizures, which are refractory to anticonvulsant treatment. In this disorder, the basic abnormality is the defective intestinal absorption of magnesium. Mutations in TRPM6, the gene encoding the transient receptor potential cation channel subfamily member 6 have been found to be responsible for this disease. We report on a four-month-old Tunisian girl who presented with convulsions. Laboratory evaluation yielded extremely low serum magnesium levels, low calcium levels, and abnormal PTH levels. The diagnosis of HSH was confirmed by mutation analysis which identified the novel mutation c.1307A $>\mathrm{G}$ in exon 11 of TRPM6 (Lys436Arg). Our patient was homozygous for this mutation. Prenatal diagnosis was done during second pregnancy. DNA from trophoblast biopsy showed the same mutation as the proband.
\end{abstract}

\section{Keywords}

Magnesium, Hypomagnesemia, Hypocalcemia, Convulsion, TRPM6

\section{Introduction}

Hypomagnesemia with secondary hypocalcemia (HSH) is an autosomal recessive disease that results in electrolyte abnormalities shortly after birth [1] [2]. Affected individuals presented generalized convulsions or signs of increased neuromuscular excita- 
bility [3] [4]. The low serum magnesium which characterizes this disorder is related to defective intestinal magnesium absorption [4] [5]. Impaired synthesis and secretion of parathyroid hormone (PTH) as a consequence of profound hypomagnesemia have been suggested to be responsible for the observed hypocalcemia [6] [7]. Restoring the concentrations of serum magnesium to normal values by high-dose magnesium supplementation can overcome the apparent defect in magnesium absorption and in serum concentrations of calcium [8]. Delay in diagnosis resulted in permanent neurologic damage [6].

We report a Tunisian girl affected by HSH. Through her case report, we elucidated the importance to recognize hypomagnesemia as the primary cause of neurologic symptoms and we detailed approaches to diagnosis and treatment of $\mathrm{HSH}$.

\section{Case Report}

A four-month-old girl of Tunisian origin presented with generalized convulsions without fever or trauma. She was born at term and there was no specific finding in medical history. The parents were second degree cousins. Physical examination noted a wide anterior fontanelle. Laboratory results revealed normal blood glucose and electrolytes. However, serum $\mathrm{Mg}^{+2}$ and $\mathrm{Ca}^{+2}$ were low being $1.6 \mathrm{mmol} / \mathrm{l}$ and $0.23 \mathrm{mmol} / 1$ respectively. Serum PTH was $18 \mathrm{pg} / \mathrm{ml}(10-65 \mathrm{pg} / \mathrm{ml})$, serum phosphorus level: $1.43 \mathrm{mmol} / \mathrm{l}$, PAL: 247UI/l, 25OHvitD: $34.6 \mathrm{ng} / \mathrm{ml}(20-40 \mathrm{ng} / \mathrm{ml})$. The patient showed no clinical or radiological evidence for rickets but was treated accordingly. Two months later, she was referred to our hospital because of recurrent seizures. CSF analysis revealed pneumococcal meningitis. Despite Clonazepam and a well conducted antibiotic therapy, seizures persisted. Electroencephalogram and magnetic resonance imaging did not show any specific findings. Blood examination revealed hypocalcemia $(1.92 \mathrm{mmol} / \mathrm{l})$ with hypomagnesemia $(0.22 \mathrm{mmol} / \mathrm{l})$. Serum PTH was $25 \mathrm{pg} / \mathrm{ml}(10-65 \mathrm{pg} / \mathrm{ml})$. Blood glucose, electrolytes, renal fonction tests, levels of urinary ions and calcium excretion were normal. Fractional magnesium excretion $\left(\mathrm{FE} \mathrm{Mg}^{+2}\right)$ was $1.4 \%$. There was no nephrocalcinosis on renal ultrasonography. A normal serum level of calcium and magnesium was restored with intra venous calcium gluconate and magnesium sulphate, leading to control seizures. After cessation of parenteral magnesium sulphate, we started oral supplementation. However, the serum magnesium level rapidly decreased from $0.74 \mathrm{mmol} / \mathrm{l}$ to $0.34 \mathrm{mmol} / \mathrm{l}$ within three days, while serum level of calcium remained in normal limits. To keep our patient symptom free and normocalcaemic, a high dose of enteral magnesium was required. In fact, she received $145 \mathrm{mg} / \mathrm{kg} / \mathrm{j}(6 \mathrm{mmol} / \mathrm{kg} / \mathrm{j})$ of magnesium pidolate which increased serum magnesium level to $0.68 \mathrm{mmol} / \mathrm{l}$. A gastrointestinal cause of hypomagnesemia was suspected. As the clinical picture and the laboratory results in serum and urine pointed toward hypomagnesemia with secondary hypocalcemia, the TRPM6 gene was screend for mutations, which identified the novel mutation c.1307A $>$ G in exon 11 of TRPM6 (Lys436Arg). In addition to the aminoacid exchange, the mutation affects the donor splice site of exon 11 of the TRPM6 gene. According to splice prediction programs, it is most likely that exon 11 of the TRPM6 gene 
is skipped form the mature mRNA. Skipping of exon 11 will cause a deletion (c.1208 $1308 \mathrm{del}$ ) resulting in a premature stop coding (pGly403AlafsX2). Both parents of Sabrine are each heterozygous for the above mentioned mutation. The mother of the proband is 25 years old and the father is 37 years old. Serum magnesium level was 0.44 $\mathrm{mmol} / \mathrm{l}$ for the mother and $0.84 \mathrm{mmol} / \mathrm{l}$ for the father. None had a history of convulsions but the mother expressed paresthesia. At the age of 3 years, the patient suffered from mental impairment. She was under magnesium supplementation with sodium valproate. The main side effect of oral magnesium was diarrhea. When the drug compliance was poor, she presented seizures and she required, occasionnaly, intravenous infusion of magnesium. Prenatal diagnosis was done during second pregnancy. DNA from trophoblast biopsy showed homozygousity for c.1307A >G in exon 11 of TRPM6 (Lys436Arg).

\section{Discussion}

Hypomagnesemia with secondary hypocalcemia (HSH) is a rare autosomal-recessive disorder that appears in early infancy [1] [2]. HSH is quite rare in all races [3]. To our knowledge, this is the first Tunisian case identified with the novel mutation c.1307A $>\mathrm{G}$ in exon 11 of TRPM6. HSH is characterized by severe hypomagnesemia leading to low serum calcium levels [9]. The observed hypocalcemia is due to impaired synthesis and secretion of parathyroid hormone (PTH) as a consequence of profound hypomagnesemia [10] [11]. The low serum magnesium levels result from defective intestinal magnesium absorption and increased renal magnesium clearance [10] [12]. There was an association between HSH and mutations in the gene encoding the transient receptor potential channel melastatin 6 (TRPM6), which is involved in transepithelial magnesium transport and belongs to the transient receptor potential (TRP) family of cation channels [12]. Children with HSH are commonly reported as presenting with tetany, or convulsions, or both [2]. In the present case, the initial clinical manifestations were generalized hypocalcaemic seizures, as it was reported by Shalev et al. [2]. In fact, among 15 patients with $\mathrm{HSH}$, the most common presenting events (67\%) were generalized seizures at a mean age of 4.9 weeks [2].

The very low serum $\mathrm{Mg}^{2+}$ of our patient was considered, firstly, as a transient phenomenon. Recurrent convulsions with persistent hypocalcaemia and hypomagnesemia, despite treatment with vitamin $\mathrm{D}$ and calcium, led to exclude the diagnosis of nutritional rickets. Further investigations were done to exclude Gitelman and Bartter syndroms. The normal renal ultra sonography and urinary calcium excretion were not suggestive of familial hypomagnesemia with hypercalciuria and nephrocalcinosis. Acute intravenous magnesium infusion leading to relief of clinical symptoms and normocalcemia and requirement of high doses of oral magnesium to remain the serum magnesium in the subnormal range are suggestive of HSH. Shalev et al. affirmed that blood magnesium concentrations of their patients with $\mathrm{HSH}$ did not fully normalise dispite high doses of enteral magnesium [2].

HSH was confirmed, in our patient, by genetic analysis which identified the novel 
mutation c.1307A >G in exon 11 of TRPM6. On one hand this mutation is a missense mutation (Lys436Arg), on the other hand the mutation damages the donor splice site of exon 11 of the TRPM6 gene. By this, most likely exon 11 is skipped from the TRPM6 mRNA resulting in a non-functional transcript with a premature stop coding (pGly403AlafsX2). Katayama et al reported that no genotype-phenotype correlation exists for HSH [12]. A good neurodevelopmental outcome could be achieved in affected children who were treated with the appropriate long term dosage of enteral magnesium [2].

Failure of early diagnosis of $\mathrm{HSH}$ or non compliance with treatment recommendations can be detrimental causing permanent neurological damage and even a death [2]. Our patient exhibited mental retardation. Pneumococcal meningitis, repeated convulsions and low drug comlpiance contributed to mental impairment.

Considering early diagnosis of HSH allows protection of the child, prenatal diagnosis was performed for the proband's modher during second pregnancy. As the expected new baby have the same mutation of her sister, careful clinical observation during newborn period with control of serum levels of magnesium may indicate the appropriate time for initiation of magnesium supplementation. Apa et al reported a new born whith HSH who presented with atonic seizures that first occurred on the $20^{\text {th }}$ day of life. This patient had a normal mental and motor development under treatment [6].

\section{Conclusion}

In conclusion, this case highlights the importance to distinct $\mathrm{HSH}$ from other disorders which also have hypomagnesemia as a symptom [10] [13]. Any delay in the diagnosis of this rare disease may affect neurodevelopmental outcome [2].

\section{References}

[1] Walder, R.Y., Landau, D., Meyer, P., Shalev. H., et al. (2002) Mutation of TRPM6 Causes Familial Hypomagnesemia with Secondary Hypocalcemia. Nature Genetics, 31, 171-174. https:/doi.org/10.1038/ng901

[2] Shalev, H., Phillip, M., Galil, A., Carmi, R. and Landau, D. (1998) Clinical Presentation and Outcome in Primary Familial Hypomagnesaemia. Archives of Disease in Childhood, 78, 127-130. https:/doi.org/10.1136/adc.78.2.127

[3] Zhao, Z., Pei, Y., Huang, X., Liu, Y., et al. (2013) Novel TRPM6. Mutations in Familial Hypomagnesemia with Secondary Hypocalcemia. American Journal of Nephrology, 37, 541548. https:/doi.org/10.1159/000350886

[4] Visudhiphan, P., Visudtibhan, A., Chiemchanya, S., et al. (2005) Neonatal Seizures and Familial Hypomagnesemia with Secondary Hypocalcemia. Pediatric Neurology, 33, 202205. https:/doi.org/10.1016/j.pediatrneurol.2005.03.009

[5] Chubanov, V., Gudermann, T. and Schlingmann, K.P. (2005) Essential Role for TRPM6 in Epithelial Magnesium Transport and Body Magnesium Homeostasis. Pflugers Archiv, 451, 228-234.

[6] Apa, H., Kayserili, E., Agin, H., Hizarcioglu, M., Gulez, P. and Berdeli, A. (2008) A Case of Hypomagnesemia with Secondary Hypocalcemia Caused by Trpm6 Gene Mutation. Indian Journal of Pediatrics, 75, 632-634. https:/doi.org/10.1007/s12098-008-0121-7

[7] Lainez, S., Schlingmann, K.P., van der Wijst, J., et al. (2014) New TRPM6 Missense Muta- 
tions Linked to Hypomagnesemia with Secondary Hypocalcemia. European Journal of Human Genetics: EJHG 22, 497-504. https:/doi.org/10.1038/ejhg.2013.178

[8] Schlingmann, K.P., Sassen, M.C., Weber, S., et al. (2005) Novel TRPM6 Mutations in 21 Families with Primary Hypomagnesemia and Secondary Hypocalcemia. Journal of the American Society of Nephrology. JASN, 16, 3061-3069.

https:/doi.org/10.1681/ASN.2004110989

[9] Walder, R.Y., Shalev, H., Brennan, T.M.H., Carmi, R., et al. (1997) Familial Hypomagnesemia Maps to Chromosome 9q, Not to the X Chromosome: Genetic Linkage Mapping and Analysis of a Balanced Translocation Breakpoint. Human Molecular Genetics, 6, 1491 1497. https:/doi.org/10.1093/hmg/6.9.1491

[10] Cole, D.E. and Quamme, G.A. (2000) Inherited Disorders of Renal Magnesium Handling. Journal of the American Society of Nephrology: JASN, 11, 1937-1947.

[11] Hoorn, E.J. and Zietse, R. (2013) Disorders of Calcium and Magnesium Balance: A Physiology-Based Approach. Pediatric Nephrology, 28, 1195-1206.

https:/doi.org/10.1007/s00467-012-2350-2

[12] Katayama, K., Povalko, N., Yatsuga, S., et al. (2015) New TRPM6 Mutation and Management of Hypomagnesaemia with Secondary Hypocalcaemia. Brain \& Development, 37, 292-298. https:/doi.org/10.1016/j.braindev.2014.06.006

[13] Konrad, M. and Weber, S. (2003) Recent Advances in Molecular Genetics of Hereditary Magnesium-Losing Disorders. Journal of the American Society of Nephrology: JASN, 14, 249-260. https:/doi.org/10.1097/01.ASN.0000049161.60740.CE

\section{Submit or recommend next manuscript to SCIRP and we will provide best service} for you:

Accepting pre-submission inquiries through Email, Facebook, LinkedIn, Twitter, etc. A wide selection of journals (inclusive of 9 subjects, more than 200 journals)

Providing 24-hour high-quality service

User-friendly online submission system

Fair and swift peer-review system

Efficient typesetting and proofreading procedure

Display of the result of downloads and visits, as well as the number of cited articles

Maximum dissemination of your research work

Submit your manuscript at: http://papersubmission.scirp.org/

Or contact ojped@scirp.org 